\title{
Jövedelmi helyzet, jövedelmi egyenlőtlenségek
}

\author{
Fábián Gergely ${ }^{1}$, Takács Péter $^{2}$, Szigeti Fruzsina ${ }^{3}$ \\ ${ }^{1}$ Főiskolai tanár, Debreceni Egyetem Egészségügyi Kar, 4400 Nyíregyháza, Sóstói u. 2-4 \\ ${ }^{2}$ Főiskolai tanár, Debreceni Egyetem Egészségügyi Kar, 4400 Nyíregyháza, Sóstói u. 2-4 \\ ${ }^{3} \mathrm{PhD}$ hallgató, Debreceni Egyetem Bölcsészettudományi Nevelés és Művelődéstudományi Doktori Program 4032 \\ Debrecen, Egyetem tér 1
}

\section{INFO}

Fábián Gergely

fabian.gergely@foh.unideb.hu

\section{Keywords}

income

inequalities

poverty

quality of life

\section{Kulcsszavak}

jövedelmek

jövedelmi

egyenlötlenségek

szegénység

életminőség

\section{ABSTRACT}

Income conditions, income inequalities. Nyíregyháza faced the strongest effects of the economic and social crisis between 2008 and 2010. While the employment rate decreased, the number of the unemployed and the proportion of people living in poverty increased.

The period of recovery from the crisis was between 2010 and 2012. The proportion of the employed grew, the income increased also in nominal terms, and the proportion of people living in poverty also showed a slight decrease. Favorable trends continued between 2012 and 2015, but especially after 2015, the employment, the net income, including median income increased. The growth did not completely cover the society of the city, as for the lowest income decile nominal decline can be measured. Apart from this the situation of each group has been more favorable by 2018. This change can be measured well in the subjective judgment of the income situation. At the same time, as incomes have increased for each group, but not to the same extent, the level of inequalities remained unchanged, or, due to the "distancing" of the lower decile they even slightly increased. However, growth did not automatically mean an increase in poverty; the relative poverty rate even declined by one percentage point between 2012 and 2015 and by nearly 2 percentage points between 2015 and 2018 compared to 2010 .

Absztrakt. Nyíregyháza városában a gazdasági-társadalmi
válság hatásai 2008 és 2010 között voltak a legerőteljeseb-
bek. Csökkent a foglalkoztatottság, nőtt a munkanélküliek
száma, és nőtt a szegénységben élök aránya is. A 2010 és
2012 közötti periódus a válságból való kilábalás időszaka
volt, nőtt a foglalkoztatottak aránya, nominális értékben is
nőttek a jövedelmek, a szegénységben élők aránya is enyhe
csökkenést mutatott.




\begin{abstract}
A kedvező tendenciák folytatódtak 2012 és 2015 között is, de különösen 2015 után, nött a foglalkoztatottság, nöttek a nettó jövedelmek, ideértve a mediánjövedelmet is. A növekedés nem teljesen terült szét a város társadalmi terében, hiszen a legalsó jövedelmi decilis esetében nominális csökkenés mérhetö, ettől eltekintve azonban minden csoport helyzete kedvezőbb lett 2018-ra. Ez a változás jól mérhető a jövedelmi helyzet szubjektív megítélése esetében is.

Ugyanakkor az egyenlötlenségek mértéke nem változott, illetve az alsó decilis „távolodása” miatt, még némileg növekedtek is. A növekedés azonban nem jelentette automatikusan a szegénység növekedését is, sőt a relatív szegénység mértéke 2012 és 2015 között egy százalékponttal, míg 2015 és 2018 között közel 2 százalékponttal csökkent 2010-hez viszonyítva.
\end{abstract}

Ez a tanulmány a Nyíregyháza város életminősége - Háztartáspanel kutatás Egészségi állapot felmérése keretében készült.

\title{
Bevezetés
}

Tanulmányunkban a nyíregyházi háztartásokban keletkező és mérhető jövedelmek alakulását és azok eltéréseit vizsgáljuk. Az elemzések alapját a 2018-as életminőség vizsgálat képezte (bővebbel lásd. Fábián és mtsai, 2018; valamint Huszti és mtsai, 2018). A jövedelmekhez kapcsolódóan definiáljuk és elemezzük a szegénységet is, így a relatív szegénységet, pontosabban a jövedelmi szegénységet vizsgáljuk, mivel ez köthető a legszorosabban a jövedelmi egyenlötlenségekhez.

A relatív, vagy más néven a jövedelmi szegénység alatt az Európai Unió Bizottsága által 2001-ben elfogadott ún. Laekeni indikátorokat vettük alapul, amelyek alapján a szegénységi küszöb a medián ekvivalens jövedelem (nemzeti valutában mért) 60 százaléka. ${ }^{1}$

\section{Jövedelmek és egyenlőtlenségek}

A jövedelmek vizsgálatánál a háztartásokban keletkező nettó, szabadrendelkezésủ jövedelmek jellemzöit és különböző eloszlásait elemezzük, nincsenek információk a

\footnotetext{
${ }^{1}$ A medián ekvivalens jövedelem azt jelenti, hogy a felmért népességet az OECD 2 fogyasztási egységre jutó jövedelem alapján sorba rendezzük, melynek alapján a sor közepén lévő jövedelem jelenti a mediánt, amelyhez képest pontosan ugyanannyinak van kevesebb, illetve több jövedelme. Az OECD 2 fogyasztási egységkulcs azt jelenti, hogy a háztartás egyes tagjaihoz súlyokat rendelünk. Ez alapján az első felnőtt 1, minden további felnőtt 0,5 , a 14 év alattiak pedig 0,3 egységet képviselnek. Bár az elfogadott indikátorok alapján a nemzetközi összehasonlítások is az OECD 2 skálát alkalmazzák, elterjedtek az egyéb számítási módok is (pl. az OECD 1 skála), amelyek némileg eltérő súlyokat alkalmaznak, közös jellemzőjük azonban mindig az, hogy kizárólag a jövedelmekre alapoznak.
} 
bruttó jövedelmekről, illetve a bruttó és nettó jövedelmek „,viszonyáról”. Eddigi kutatási eredményeink alapján elmondható, hogy 2008 és 2018 között a város jövedelmi helyzetének jellemzői, illetve annak változásai számos esetben „lekövették” az országos tendenciákat. 2008 és 2010 között csökkent az egy före jutó jövedelem átlaga, az akkor kirobbant gazdasági-financiális válság hatására, míg 2010-től folyamatos növekedés figyelhető meg. 2010 és 2017 között országosan 37 százalékkal, míg a városban valamivel erőteljesebben, 40 százalékkal nőtt az átlagjövedelem.

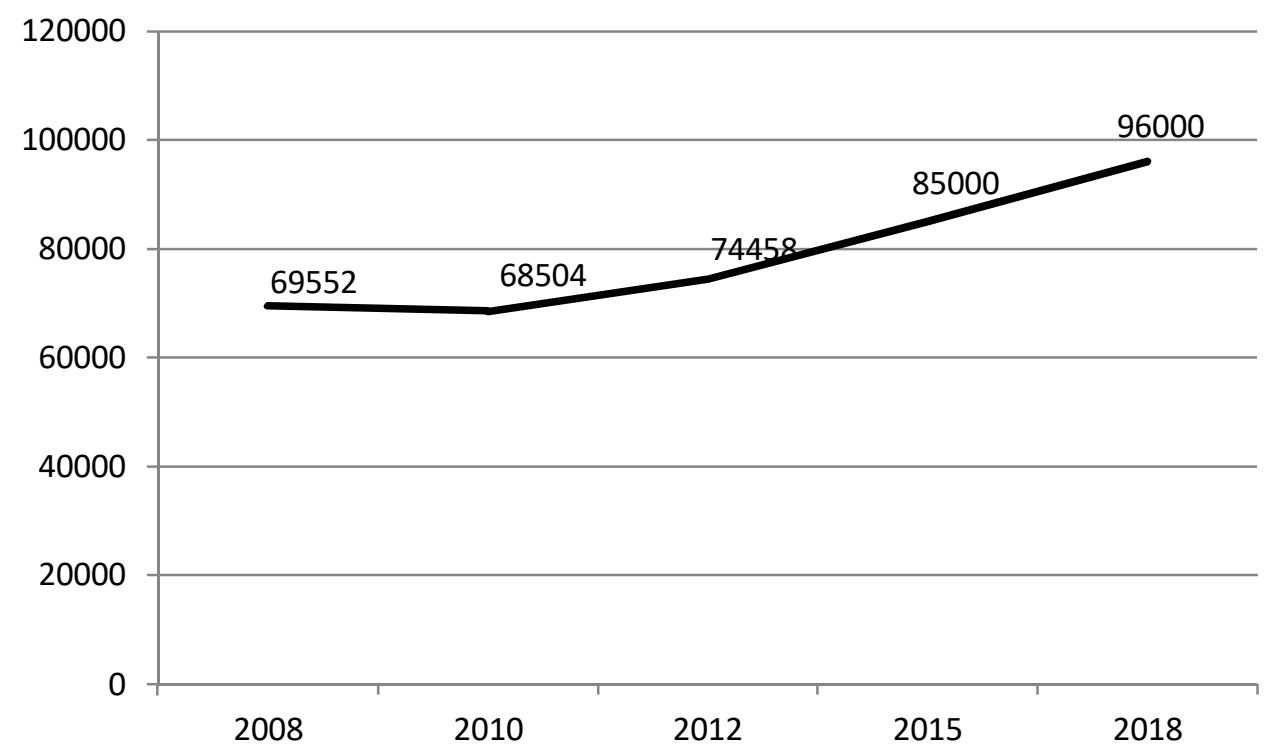

(Forrás: Nyíregyháza életminősége, 2018)

1. ábra: Az átlagjövedelem alakulása Nyíregyháza városában - az egy före jutó háztartási jövedelmek alapján (átlagértékek, forintban).

Az átlagjövedelem növekedése elsősorban 2012-2013-tól vált dinamikusabbá. A legutóbbi, 2015-ös adatfelvételünkhöz viszonyítva, a növekedés üteme 2017-re elérte a 13 százalékos arányt. A nyíregyházi átlagjövedelem ugyanakkor néhány ezer forinttal még mindig elmarad az országostól, hiszen a KSH számításai szerint ez az összeg 2015-ben országosan 96.000, míg 2017-ben 108.000 forint volt. ${ }^{2}$ Az átlagjövedelem növekedése ugyanakkor mindenképpen pozitívan értékelhető fejlemény.

A jövedelmek vizsgálatánál az átlagérték egy igen jól használható mutató, különösen az időbeli és térbeni összehasonlítások tekintetében, mégis „csalóka” lehet sok esetben, mivel elfed(het) olyan különbségeket, amelyek erőteljesen meghatározhatják a lakosok életminőségét. Ez a helyzet Nyíregyháza esetében is, hiszen a városra jellemző átlagjövedelem alatti jövedelemből élt a lakosok 57 százaléka, ez a mutató gyakorlatilag változatlan 10 éve. Ez alapján az is látható, hogy az átlag nem „középen" van, ezért minden egyes alkalommal figyelembe kell venni a mediánjövedelmet, amely valódi középértéket mutat, azaz kétfelé osztja a lakosokat a jövedelem

\footnotetext{
${ }^{2}$ KSH: A háztartások életszínvonala, 2017.
} 
alapján. 2008-ban és 2010-ben a medián értéke 62.500 forint volt, gyakorlatilag „mozdulatlan” volt, míg 2012-ben már enyhén növekedett, elérte a 66.666 forintot. 2015-ben 75.000 forint, míg 2018-ban 87.500 forintra nőtt a medián értéke. A medián értéke ugyan szerényebb mértékben növekedett, mint az átlagjövedelem (a medián értékének növekedése 2015 és 2018 között 16 százalékos volt), ez azonban jelentősen meghaladta az adott időszakra vonatkozó infláció mértékét (a teljes, kumulált infláció növekedése 2.7 százalékos volt), így a városban, az elmúlt két évben a jövedelmek reálértékben is növekedtek.

Az átlagjövedelem és a mediánjövedelem örvendetes növekedésének hátterében több makrogazdasági és makrotársadalmi változás, intézkedés áll. Ilyen volt - többek között - a minimálbér, a garantált bérminimum vagy a nyugdíjak emelése, de a város tekintetében talán a legfontosabb a foglalkoztatottság növekedése, amely 2017-re elérte a 68 százalékot. Ez jelentős növekedés a 2015-ös 54 százalékos arányhoz képest. ${ }^{3}$ Nyíregyháza városa ezzel az adattal gyakorlatilag „utolérte” az országot, hiszen a KSH közlése szerint ebben az évben a foglalkoztatási ráta a 15-64 évesek körében $68,2 \%$ volt.

A városlakók szubjektív megítélése is javult, hiszen 2018-ban jóval magasabb volt azoknak az aránya 2015-höz képest, akik úgy vélekedtek, hogy javult az anyagi helyzetük, és alacsonyabb azoké, akik inkább romlásról számoltak be.

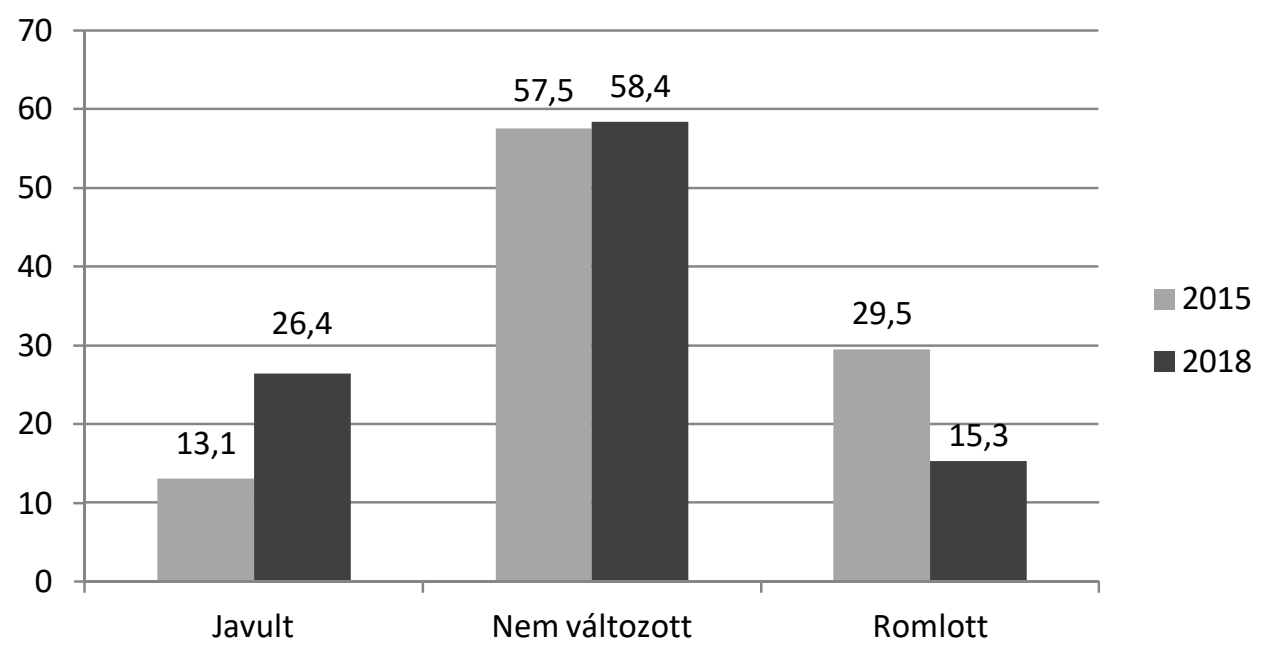

(Forrás: Nyíregyháza életminösége, 2018)

2. ábra: A háztartás anyagi helyzetének megítélése a megkérdezést megelőző évekhez viszonyítva (százalékban).

3 A foglalkoztatottságról, a gazdasági aktivitásról, illetve azok változásáról részletes információkat közöl R. Fedor Anita ebben a kötetben a Foglalkoztatási helyzetkép és a munkával való elégedettség jellemzői című tanulmányában. 
Azok aránya, akik úgy vélik, hogy nem változott a háztartás anyagi helyzete, szinte változatlan, ugyanakkor pozitív elmozdulásról, azaz javulásról jóval többen számolnak be, mint a korábbi években (arányuk megduplázódott), illetve jelentősen csökkent azok aránya, akik inkább romlást érzékelnek. (2. ábra)

A pozitív tendenciák mellett az a tény, hogy a lakosok 57 százaléka továbbra is alacsonyabb átlagjövedelemből él, arra hívja fel a figyelmet, hogy a jövedelmi egyenlőtlenségek továbbra is jellemzőek a városban, sőt az adatok arra utalnak, hogy ebben az esetben enyhe növekedés figyelhető meg.

\begin{tabular}{|c|c|c|c|c|c|}
\hline Mutatók & $\mathbf{2 0 0 8}$ & $\mathbf{2 0 1 0}$ & $\mathbf{2 0 1 2}$ & $\mathbf{2 0 1 5}$ & $\mathbf{2 0 1 8}$ \\
\hline S10/S1 & 7,2 & 6,6 & 7,7 & 7,5 & 10,2 \\
\hline $\begin{array}{c}\text { Robin } \\
\text { Hood } \\
\text { index }\end{array}$ & 20,0 & 20,0 & 20,0 & 20,0 & 21,0 \\
\hline $\begin{array}{c}\text { Éltetö } \\
\text { Frigyes } \\
\text { index }\end{array}$ & 2,21 & 2,25 & 2,26 & 2,27 & 2,3 \\
\hline GINI & 0,285 & 0,290 & 0,290 & 0,290 & 0,290 \\
\hline
\end{tabular}

(Forrás: Nyíregyháza életminősége, 2018)

1. táblázat: A jövedelmi egyenlőtlenségek egyes mutatóinak változása Nyíregyháza városában, 2008-2018.

Bár a GINI értéke változatlan, a többi index értéke enyhe növekedést mutat, ami arra utal, hogy a városban, kis mértékben ugyan, de nőttek a jövedelmi egyenlötlenségek, ezért érdemes megvizsgálni a jövedelmi decilisek helyzetét.

\begin{tabular}{|l|c|c|c|}
\hline & 2012 & 2015 & 2018 \\
\hline Alsó decilis & 22,487 & 29,057 & 22,053 \\
\hline 2. Decilis & 38,359 & 43,864 & 46,093 \\
\hline 3. Decilis & 48,482 & 50,835 & 57,811 \\
\hline 4. Decilis & 56,787 & 62,552 & 66,034 \\
\hline 5. Decilis & 63,748 & 73,173 & 78,177 \\
\hline 6. Decilis & 72,450 & 81,604 & 91,474 \\
\hline 7. Decilis & 81,211 & 90,697 & 100,820 \\
\hline 8. Decilis & 95,185 & 100,007 & 122,594 \\
\hline 9. Decilis & 113,259 & 113,571 & 148,958 \\
\hline Felsö decilis & 174,524 & 217,818 & 225,357 \\
\hline
\end{tabular}

\begin{tabular}{|l|c|c|c|}
\hline S10/S1 & 7,7 & 7,5 & 10,2 \\
\hline
\end{tabular}

(Forrás: Nyíregyháza életminösége, 2018)

2. táblázat: A jövedelmek egyenlőtlenségei Nyíregyháza városában - az egy före jutó háztartási jövedelmek eloszlása a jövedelmi tizedek szerint, 2012-2018. (Átlagértékek, forintban)

A legalsó decilis esetében mérhető nominális csökkenés az előző adatfelvétel időszakához képest, ugyanakkor a többi csoport esetében növekedés mérhetö, különösen a „felső középosztályhoz” és a ,jómódúakhoz” sorolható 7,8,9 decilisek eseté- 
ben. Ez egyben azt is jelenti, hogy ha eltekintünk az alsó decilis helyzetétöl, akkor minden tized esetében növekedésröl beszélhetünk, azaz a jövedelmek emelkedése majdnem teljesen szétterült a társadalmi térben. Már ez a tény is megmagyarázza az egyenlőtlenségek fennmaradását. Annak hátterében, hogy az egyes mutatók értéke növekedett, az áll, hogy a jövedelmek növekedése eltérő mértékü volt az egyes csoportoknál, illetve, hogy az alsó decilis esetében csökkenés mérhető. (2. táblázat)

Bár országosan az S10/S1 mutató értéke alacsonyabb (valamivel 8 feletti), az egyenlőtlenségek mértéke ugrásszerüen nőtt Magyarországon is, elsősorban 2016 és 2017 között, hiszen a GINI értéke egy év leforgása alatt 28,1 százalékról 28,7 százalékra nőtt, míg az ún. S80/S20 mérőszám értéke 4,3-ról 4,4-re (KSH,2018). (2. táblázat)

A korábbi kutatásainkból már megismert és meghatározó változók esetében továbbra is a háztartás létszáma, illetve az iskolázottság gyakorolja a legerőteljesebb hatást a jövedelmek tekintetében.

\begin{tabular}{|l|c|c|}
\hline & 2010 & 2018 \\
\hline 1 fơs háztartás & 103,532 & 132,243 \\
\hline 2 fós háztartás & 81,548 & 115,843 \\
\hline 3 fös háztartás & 63,418 & 82,894 \\
\hline 4 fös háztartás & 53,759 & 67,549 \\
\hline 5 fös háztartás & 43,306 & 45,411 \\
\hline
\end{tabular}

3. táblázat: A jövedelmek egyenlőtlenségei Nyíregyháza városában - az egy före jutó háztartási jövedelmek eloszlása a háztartás nagysága szerint, 2010 és 2018. (Átlagértékek, forintban)

Bár minden egyes csoportban növekedés mérhető 2010-hez képest, a legkisebb mértékü növekedés az 5 fós háztartások esetében figyelhető meg.

\begin{tabular}{|l|c|c|}
\hline & 2010 & 2018 \\
\hline 8 általános alatt & 50,543 & 43,333 \\
\hline 8 általános & 55,238 & 64,973 \\
\hline Szakiskola & 56,348 & 88,482 \\
\hline Szakközépiskola & 65,030 & 93,930 \\
\hline Gimnázium & 71,390 & 96,371 \\
\hline Föiskola & 84,668 & 108,431 \\
\hline Egyetem & 88,395 & 114,470 \\
\hline
\end{tabular}

(Forrás: Nyíregyháza életminősége, 2018)

4. táblázat: A jövedelmek egyenlőtlenségei Nyíregyháza városában - az egy főre jutó háztartási jövedelmek eloszlása a megkérdezettek iskolai végzettsége alapján, 2010 és 2018.

(Átlagértékek, forintban)

\footnotetext{
${ }^{4}$ A leggazdagabb és a legszegényebb 20 százalék jövedelme közötti különbség. Ennek a mutatónak az értéke 4,3 Nyíregyháza városában.
} 
2010-hez képest egy csoport (8 általános alatt) esetében csökkent a jövedelem, minden más csoportban növekedés jellemző, azzal, hogy a végzettségek alapján a különbségek továbbra is meghatározóak. (4. táblázat)

\section{Jövedelmi szegénység}

A jövedelmi egyenlőtlenségek növekedése korántsem jelenti azt, hogy nőtt a szegénységben élők aránya. Erre nem elsősorban az átlagjövedelem alakulása, hanem a mediánjövedelem növekedése utal, illetve a szegénységi ráták számításához alkalmazott mediánjövedelem (a medián 60 százaléka), ami egyben a szegénységi küszöböt jelenti. Ez az összeg 2008-ban és 2010-ben is 37.500 forint volt, 2012-töl folyamatosan emelkedett, míg 2018-ra elérte az 52.500 forintot. A jövedelmi szegénység számításához Nyíregyháza esetében is az OECD2 skálát alkalmaztuk. ${ }^{5}$

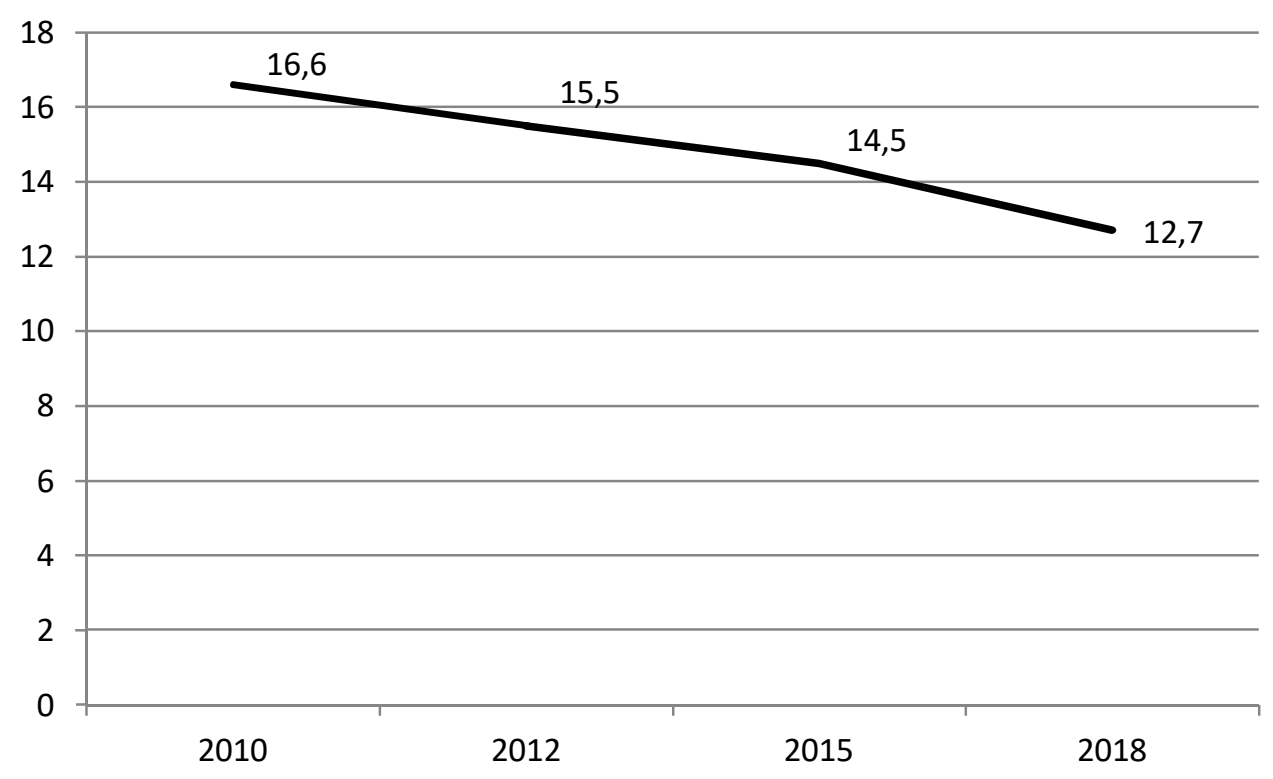

(Forrás: Nyíregyháza életminősége, 2018)

3. ábra: A jövedelmi szegénység alakulása Nyíregyháza városában, 2010-2018 között (százalékban)

A jövedelmi helyzet javulásával a szegénység is csökkent a városban. Ez a tendencia szintén „leképezi” a hazai változásokat, hiszen hazánkban a jelzett időszakban

\footnotetext{
${ }^{5}$ A szegénységi küszöb az OECD2 skála alapján számolva a mediánjövedelem 60 \%-a. (Skála: felnőtt 1 , további felnőtt 0.5 , gyermek 0.3 súlyú fogyasztási egység)
} 
közel 15 százalékról 12,8 százalékra csökkent a jövedelmi szegénységben élök aránya. ${ }^{6}$ (3.ábra)

A szegénység rizikóját figyelembe véve, a városban hasonló különbségek figyelhetők meg, mint országosan. A nők körében magasabb ráták mérhetőek (15,8\%), mint a férfiak esetében $(9,4 \%)$, illetve az aktív korúak körében is magasabb értékek mérhetőek, mint a 65 év felettiek körében (14,0 illetve 4,9 százalék). Megjegyzendő, hogy az idősek körében kedvezőbb a helyzet, mint országosan, a hazai ráta ugyanis 9,8\% A jövedelmi deciliseket figyelembe véve a legalsó decilis, illetve részben a második decilisből kerülnek ki a szegények. (4.ábra)

A párkapcsolatban élés protektív faktornak bizonyul jövedelmi szempontból is, ebben az esetben elsősorban (természetesen) azzal kell számolnunk, hogy az adott háztartásban minimum két fö rendelkezik jövedelemmel, függetlenül attól, hogy esetükben a munkajövedelmek dominálnak, vagy az idősebbek esetében két nyugdíj áll rendelkezésre.

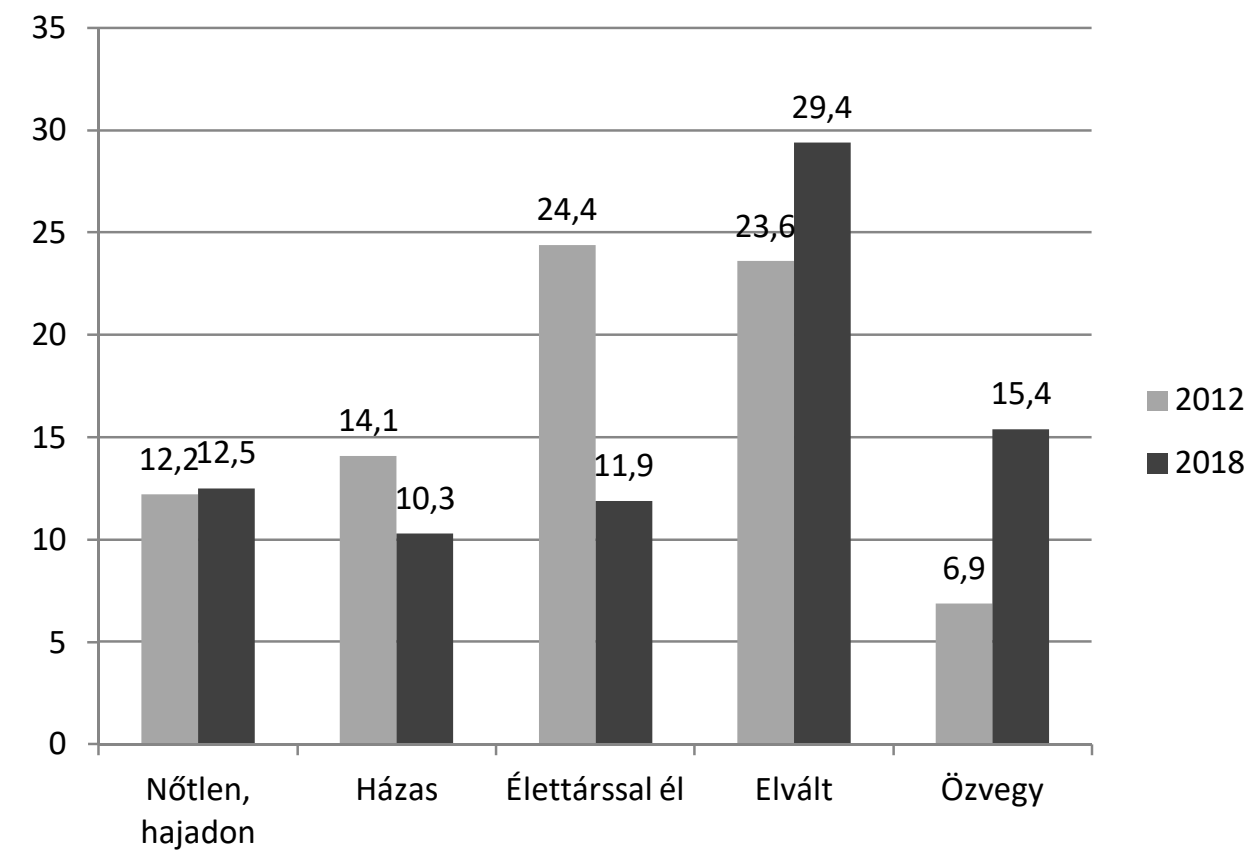

(Forrás: Nyíregyháza életminősége, 2018)

4. ábra: A jövedelmi szegénység alakulása Nyíregyháza városában, 2012-2018 között, a családi állapot függvényében (százalékban).

\footnotetext{
${ }^{6}$ Az országos adatok forrása A háztartások életszínvonala, 2017 című KSH kiadvány. Megjegyzendő, hogy az EUROSTAT 2017-re valamivel magasabb arányt (13,4 százalék) számított Magyarország esetében, a csökkenő tendencia azonban ebben az esetben is egyértelmü. Mind Magyarország, mind a város kedvezőbb adatokkal rendelkezik az unió átlagához képest, amely 16,9 százalék volt 2017-ben. (EUROSTAT EU-SILC adatbázis)
} 
Érdekes kérdés, hogy az általunk vizsgált jellemzök hogyan és milyen mértékben befolyásolják a nyíregyházi lakosok életminőségét. Az életminőséget kutatási programunk 2010-es, második hullámában kidolgozott ún. FTI-index alkalmazásával mértük, amely 24 különböző, az életminőség legfontosabb változóinak értékeit süríti egy indexbe. Kiindulópontja az ún. Rahman-modell, amely összesen 8 dimenzióban határozza meg az életminőséget meghatározó változókat, úgymint családi és baráti viszonyok, egészségi állapot, munka és aktivitás, anyagi jólét, a környezet minősége, személyes biztonság, a lokális közösséghez tartozás érzése és az érzelmi jólét (Sebestyén, 2005). ${ }^{7}$

A 2010-2015 közötti időszakban alkalmazott index nem tartalmazta az érzelmi jólét változót, elsősorban azért, mert viszonylag kevés, magyar nyelven is hozzáférhető és már kipróbált mérőeszköz áll rendelkezésre. Elsőként 2015-ben próbáltuk ki (egyfajta „pilot” kutatásként) az ún. Oxford Boldogságmérő Kérdőívet, amely az eredmények alapján releváns információkat tartalmazott a városlakók életminőségét meghatározó egyéb változók függvényében, így 2018-ban be tudtuk építeni a lokális életminőség indexbe.

A 2015-ös vizsgálat legfontosabb eredménye volt, hogy szignifikáns különbség létezik az életkorcsoportok boldogságértékei között, vagyis minél idősebb egy korcsoport annál kisebb a boldogság átlagos értéke. Az iskolai végzettség ugyancsak hatást gyakorol az elégedettségre. A magasabb végzettségüek csoportja átlagosan boldogabb, mint az alacsonyabb kvalifikációval rendelkezőké. A Nyíregyházán élőkre egyértelmüen az optimista, a derülátó, a bizakodó kijelentések a jellemzők. A boldogság értékét a városban leginkább a munkaerö-piaci helyzet és a baráti kapcsolatok megléte befolyásolja. Az elégedettség szintje nagymértékben magasabb azoknál, akik munkahellyel rendelkeznek, de nem magasabb azoknál, akik több jövedelemmel is rendelkeznek. Ebböl az következik, hogy elsősorban nem a megélhetési javak, a jövedelem megszerzése miatt elégedettebbek azok, akik foglalkoztattak. A megelégedés hátterében sokkal inkább állhat a csapathoz tartozás érzése, a kollegiális viszony megléte, az önmegvalósítás, a karrier út kiépítése. Ugyanakkor az elégedettség szintje azoknál is magasabb, akik baráti kapcsolatokkal, kapcsolathálózattal rendelkeznek (Szigeti-Takács-Fábián, 2015).

Az Oxford Boldogságmérő Kérdőív eredményei nélkül definiált FTI érték alakulásáról általános tendenciaként az fogalmazható meg, hogy a gazdasági válság időszakában, azaz 2008 és 2010 között csökkent a nyíregyházi lakosok életminősége, 2010 óta kedvezőbb a helyzet, hiszen az FTI átlagértéke 5,7-ről 6,7-re nőtt. Az index növekedése, illetve egyes értékeinek változásai (pl. a szórás és a minimum érték csökkenése, a maximum növekedése) mindenképpen kedvezőnek mondható. A 2018-as vizsgálatban az index már tartalmazta az Oxford eredményeit is, értéke 9,7 volt. Amennyiben az index értékét meghatározó változókat vizsgáljuk az látható, hogy a nemek között nincs szignifikáns eltérés, ezzel szemben az iskolázottság, a foglalkoztatottság és a jövedelem, valamint az egészségi állapot szubjektív megítélése meghatározó az életminőség tekintetében.

\footnotetext{
${ }^{7}$ Az index kialakításának módszertani leírását tartalmazza az „Életminőség Nyíregyházán” címü kötetben 2012-ben megjelent írásunk
} 


\begin{tabular}{|l|l|l|l|l|l|}
\hline \multirow{2}{*}{ Magyarázó változók } & \multicolumn{2}{|l|}{$\begin{array}{l}\text { Nem standardi- } \\
\text { zált koefficiensek }\end{array}$} & $\begin{array}{l}\text { Standardizált } \\
\text { koefficiensek }\end{array}$ & \multirow{2}{*}{ t } & \multirow{2}{*}{ Szign. } \\
\cline { 2 - 5 } & $\mathrm{B}$ & Std. Hiba & Béta & & \\
\hline Konstans & 7,480 & 1,106 & & 2,697 & 0,008 \\
\hline Dolgozik-e? & 2,123 & 0,397 & 0,321 & 5,132 & 0,000 \\
\hline Jövedelem & 0,224 & 0,070 & 0,181 & 2,800 & 0,006 \\
\hline Iskolai végzettség & 0,226 & 0,116 & 0,207 & 2,975 & 0,003 \\
\hline Egészségi állapot megítélése & 0,669 & 0,225 & 0,201 & 2,968 & 0,003 \\
\hline
\end{tabular}

(Az R értéke $=0,450, a z \mathrm{R}^{2}$ értéke $=0,203$, az AdjR négyzet értéke $=0,188$.

Forrás: Nyíregyháza életminösége, 2018)

5. táblázat: Lineáris regressziós eredmények a nyíregyháziak boldogságértékére vonatkozóan.

Bár a modellbe nem vontunk be minden számba vehető változót, mivel az elemzés jelenlegi fázisában még az FTI (bővített FTI) ,viselkedését” teszteljük (az adatok közlésénél eltekintettünk a nem szignifikáns eredmények bemutatásától, ilyen pl. a nem változó), az elemzéshez elsősorban a kemény szociológiai változókat alkalmaztuk. $^{8}$ A lineáris regresszió eredményei alapján arra következtethetünk, hogy a Rahman modell, és a modell alapján kidogozott FTI alkalmas az életminőség lokális mérésére, illetve, hogy az életminőség valóban többdimenziós fogalom, meghatározó elemei pedig a szociális helyzet (és annak különböző dimenziói), illetve az egészségi állapot. (5. táblázat)

\section{Összegzés}

Nyíregyháza városában a gazdasági-társadalmi válság hatásai 2008 és 2010 között voltak a legeröteljesebbek, csökkent a foglalkoztatottság, nőtt a munkanélküliek száma, és nőtt a szegénységben élők aránya is. Általánosságban is jól mérhető volt a jövedelmek csökkenése ebben az időszakban. 2008 és 2010 között jelentősen romlottak az általunk kidolgozott életminőség index értékei is.

A 2010 és 2012 közötti periódus a válságból való kilábalás időszaka volt, nőtt a foglalkoztatottak aránya, nominális értékben is nöttek a jövedelmek (a növekedés mind a háztartásokra jutó összjövedelem, mind az egy före jutó jövedelmek esetében mérhető volt), a szegénységben élők aránya is enyhe csökkenést mutatott, és az FTI értékei is kedvezőbbek lettek.

8 A lineáris regresszió elemzés lényege, hogy ha két változó lineáris kapcsolatban van egymással, akkor az egyik segítségével előre jelezhetjük a másik értékét. A modell kialakításához szükség van a függő és a független változó kiválasztására. A fenti modellben a függő változó az FTI-index, a független változók pedig a foglalkoztatottság, a jövedelem, az iskolázottság és az egészségi állapot, azaz annak tesztelése, milyen mértékben hatnak, milyen mértékben befolyásolják a független változók a függő változó értékét. 
A kedvező tendenciák folytatódtak 2012 és 2015 között is, de különösen 2015 után, nőtt a foglalkoztatottság, nőttek a nettó jövedelmek, ideértve a mediánjövedelmet is. A növekedés nem teljesen terült szét a város társadalmi terében, hiszen a legalsó jövedelmi decilis esetében nominális csökkenés mérhető, ettől eltekintve azonban minden csoport helyzete kedvezőbb lett 2018-ra. Ez a változás jól mérhető a jövedelmi helyzet szubjektív megítélése esetében is.

Ugyanakkor, mivel minden csoport esetében növekedtek a jövedelmek, ráadásul nem azonos mértékben, az egyenlőtlenségek mértéke sem változott, illetve az alsó decilis „távolodása” miatt, még némileg növekedtek is. A növekedés azonban nem jelentette automatikusan a szegénység növekedését is, sőt a relatív szegénység mértéke 2012 és 2015 között egy százalékponttal, míg 2015 és 2018 között közel 2 százalékponttal csökkent 2010-hez viszonyítva.

Az általunk kidolgozott életminőség index értékei is évről évre javultak, a 2018ban módosított FTI pedig alkalmasnak bizonyult a lokális életminőség többdimenziós vizsgálatára.

\section{Irodalom}

1. Fábián G., Huszti É., Hüse L., Takács P. (2018): Életminőség Nyíregyházán. A nyíregyházi nagymintás társadalomkutatások első négy hulláma a megyeszékhelyen. Szabolcs-Szatmár-Beregi Szemle 53/3: 83-102.

2. Huszti Éva, Hüse Lajos, Takács Péter, Fábián Gergely, (2018): A „Nyíregyháza Élet-minősége 2018" vizsgálat és a kutatás módszertana. Acta Medicinae et Sociologica Vol.9. No.27. 7-18.

3. KSH (2018): A háztartások életszínvonala. Budapest

4. R. Fedor Anita, (2018): Foglalkoztatási helyzetkép és a munkával való elégedettség jellemzői. Acta Medicinae et Sociologica Vol.9. No.27. 33-57.

5. Sebestyén Tibor (2005): Életminőség és boldogság. Polgári Szemle Vol. 1. No. 5.

6. Szigeti Fruzsina-Fábián Gergely-Takács Péter (2015): Az érzelmi jóllét mérése a Nyíregyházi járás településein. Acta Medicinae et Sociologica Vol. 6. No. 1819. 145-161.

7. Takács Péter-Fábián Gergely (2012): Egy lokális életminőség index kialakításának lépései. In: Fábián Gergely-Patyán László-Huszti Éva (szerk): Életminőség Nyíregyházán, 2008-2010. Debreceni Egyetem Egészségügyi Kar, Nyíregyháza. 49-69.

\section{Melléklet}

\section{A jövedelmi egyenlőtlenségekre vonatkozó mutatók:}

$\mathbf{p 1 0 / p 5 0}=$ a mutatószám az alsó jövedelmi tized felső határpontját viszonyítja a mediánhoz.

p90/p50 = a mutatószám a legfelső jövedelmi tized alsó határát viszonyítja a mediánhoz. 
p90/p10 = a mutatószám az alsó jövedelmi tized felső határpontját viszonyítja a felső jövedelmi tized alsó határpontjához.

$\mathbf{S 1 0 / S 1}=$ a legalsó decilis és a legfelső decilis átlagjövedelmének hányadosa, azaz hányszorosa a legfelső decilis átlagjövedelme a legalsónak.

Robin Hood index= az egyenlőtlenségek általános szintjének kimutatására szolgál. Kiindulópontja, hogy teljes egyenlőség esetén a jövedelmek egyenletesen oszlanak meg az egyének között, azaz mindegyik jövedelmi tizedbe a népesség összjövedelmének 10-10 százaléka esik. A Robin Hood-index ettől az egyenletes megoszlástól való eltérést mutatja: a 10 százaléknál nagyobb jövedelemaránnyal rendelkező decilisek 10 százalék feletti százalékrészeinek összegeként számolható ki. Másként megfogalmazva, ha akadna egy Robin Hood, aki a gazdagoktól elvett javakat a szegények számára szeretné újraosztani, akkor a szóban forgó index azt jelentené, hogy maximum mekkora hányadot kellene átcsoportosítani, hogy kiegyenlítődjenek a jövedelmi egyenlötlenségek.

Éltető Frigyes index: az átlag feletti és az átlag alatti jövedelmek hányadosa, azaz az átlag fölötti jövedelmek átlagát az átlag alatti jövedelmek átlagával vetjük össze. Teljes jövedelemegyenlőség esetén a mutató értéke 1, ennél nagyobb érték a jövedelmi olló nagyságát mutatja.

GINI $=$ az egyenlőtlenség olyan mértékegysége, amely 0 és 1 között vehet fel értékeket. $0=$ teljes egyenlöség, $1=$ teljes egyenlötlenség, azaz egy ember rendelkezik az összes jövedelemmel. A Gini-index azt méri, hogy egy adott országban, településen, stb. a jövedelmek eloszlása mennyiben tér el az abszolút egyenlőségtől. 